\title{
The role of land tenure in livelihood transitions from fishing to tourism
}

\author{
Michael Fabinyi ${ }^{1}$ (1)
}

Received: 9 March 2019 / Accepted: 13 August 2019 / Published online: 21 August 2019

(C) The Author(s) 2019

\begin{abstract}
Coastal tourism has been supported by the growth of middle-class tourist markets, promoted by governments who view it as an important avenue for economic growth and backed by environmental organisations who regard it as an alternative, more environmentally sustainable livelihood than capture fisheries. How policymakers and households in coastal areas negotiate the challenges and opportunities associated with growing tourism and declining capture fisheries is increasingly important. Drawing on extended ethnographic fieldwork from the Philippines between 2006 and 2018, this paper examines the transition from fishing to tourism and the consequences for one coastal community. I focus on land tenure as a key variable that shapes the effects and opportunities associated with livelihood transitions from fishing to tourism. While tourism has not been inherently positive or negative, the ability of local households to negotiate the boom and obtain the full benefits out of it is questionable. Many fishers have switched their primary livelihood activity to tourism, including the construction of tourist boats, working as tour guides or providing accommodation. However, the growth of tourism has prompted several attempts to evict the community, including from local elites who aimed to develop resorts on the coast and a recent push by the national administration to 'clean up' tourist sites around the country. I argue that land tenure in coastal communities should be more of a focus for researchers working in small-scale fisheries, as well as for researchers working on land rights.
\end{abstract}

Keywords Tourism $\cdot$ Fisheries $\cdot$ Livelihoods $\cdot$ Transition $\cdot$ Philippines $\cdot$ Land tenure

\section{Introduction}

Tourism is growing globally (UNWTO 2019), including in coastal communities once dominated by fishing livelihoods (Cheong 2005; Fabinyi 2010; Papageorgiou 2016; Su et al. 2016). Coastal tourism has been supported by the growth of middle-class tourism markets, promoted by governments who regard it as an important avenue for economic growth and backed by environmental organisations who regard it as an alternative, more environmentally sustainable livelihood than fishing (UNWTO 2019; White and Rosales 2003). Coastal tourism forms a key component of many incarnations of the 'blue economy', which aims to link economic growth to environmental conservation (Dwyer 2018; European Commission 2014; Silver et al. 2015; Voyer et al. 2018). In

Michael Fabinyi

michael.fabinyi@uts.edu.au

1 University of Technology Sydney, Ultimo, New South Wales 2007, Australia contrast, fishing livelihoods are less popular. In many cases they have been declining due to a combination of widespread overfishing and environmental degradation that has reduced the profitability and sustainability of fisheries livelihoods, as well as intensified forms of fisheries governance that have reduced fishing effort and restricted access (DA-BFAR 2004; Knudsen 2016; Pauly and Zeller 2016). How policymakers and households in coastal areas negotiate the challenges and opportunities associated with growing tourism and declining capture fisheries is increasingly important. Drawing on extended ethnographic fieldwork from the Philippines, this paper examines the transition from fishing to tourism and the consequences for one coastal community. I focus on land tenure as a key variable that shapes the effects and opportunities associated with livelihood transitions from fishing to tourism. I contend that land tenure in coastal communities should be more of a focus for researchers working in both small-scale fisheries and land rights.

While there is a broader literature on livelihood transition in coastal communities (e.g. Belton and Thilsted 2014; Betcherman and Marschke 2016; Menon et al. 2018), literature on the 
transition from fishing to tourism in coastal communities tends to focus on either the positive or negative livelihood effects. Among many environmentalists and policymakers, tourism is described as a potentially positive force that can generate income for local people in coastal communities in an environmentally sustainable way, such as through eco-tourism or user fees from dive tourism in marine protected areas (Depondt and Green 2006; Terk and Knowlton 2010). Others have shown that poor locals obtain few economic benefits promised by tourism or that tourism generates new user conflicts (Fabinyi 2010; Hoefle 2014; Majanen 2007; Oracion et al. 2005). The interactions between fishing and tourism livelihoods are complex and highly variable and have a range of documented negative and positive effects (Porter et al. 2015; Su et al. 2017; Miller 2018). A range of uneven costs and benefits have also been documented for tourism in coastal areas, more generally (e.g. Dodds 2007; Gössling 2003; Grydehøj and Hayward 2014; Tsartas 2003). This is inevitable for an issue that is fundamentally about resource access and exclusion (Hall et al. 2011; Ribot and Peluso 2003; Sikor and Lund 2009). Additionally, the 'transitions' from fishing to tourism rarely tend to be a linear process (Gibson et al. 2010; Hoefle 2014). While the variability and diversity of interactions between fishing and tourism livelihoods present problems for those seeking to draw wider lessons or conclusions about their relationship, I focus on the issue of land tenure as a key variable for understanding their relationship in this paper. I argue that land tenure serves as the crucible by which the costs and benefits of tourism for fishing livelihoods are forged.

Land tenure has long been a core theme among scholars of livelihoods and agrarian change in inland terrestrial spacesfrom historical analyses of enclosures and changes in agricultural practices (Akram-Lodhi and Kay 2010; Bernstein 2006), to struggles for land rights among peasant movements (Kerkvliet 2002; Wolf 1999), government programs of land reform (Borras 2001) and contemporary discussions of 'land grabbing' (Borras et al. 2011; Fairhead et al. 2012; Hall 2013). However, the role of land tenure is less examined in the literature on fishing and maritime communities. While discussions of marine tenure are common - often with reference to conservation or improved fisheries management (Foale et al. 2011; Ruddle and Satria 2010)_acknowledgement that fishers generally still live on the land is often perfunctory. While there is no shortage of literature discussing themes of social justice, social struggles and human rights within coastal communities (e.g. Allison et al. 2012; Bavinck et al. 2018; Bennett 2018a, 2018b; Davis and Ruddle 2012), the role of land rights for coastal communities and its relationship to fishing practices is rarely directly examined (for notable exceptions see Bavinck et al. 2017; Knudsen 2012). Discussion of various sorts of 'grabbing' processes has been emerging in recent years, including 'ocean grabbing' (Bennett et al. 2015), 'blue grabbing' (Benjaminsen and Bryceson 2012; Hill 2017) and more recently, 'coastal grabbing', which Bavinck et al. (2017: p. 1) define as 'the contested appropriation of coastal [shore and inshore] space and resources by outside interests'. While Bavinck et al. (2017) describe cases of coastal grabbing that involve conservation, aquaculture and several non-government organisations, private and government actors, tourism is not specifically highlighted as closely associated with coastal grabbing. However, tourism is recognised in other discussions (e.g. Bennett et al. 2015; McDonnell 2018) and there are examples of tourism involved in other cases of land grabbing (e.g. Ojeda 2012). In one of the most detailed studies of land tenure among coastal residents in Southeast Asia, Knudsen (2012) argues that, while pressures are increasing on coastal residents, analysts should pay attention to how social relations are reworked to the benefit of particular groups and to the exclusion of others. As Knudsen emphasises, there is considerable complexity in these processes that does not easily map onto depictions of poor communities being marginalised by rich outsiders in straightforward grabbing processes. The interaction between coastal communities, land rights and the emerging growth of coastal and maritime tourism is the focus of this paper. I focus specifically on how land tenure mediates tourism costs and benefits for coastal communities previously more engaged in fishing.

Land tenure is particularly important for the relationship between fishing and tourism for two reasons. First, land tenure of many coastal communities tends to be weak - associated with informal settlements, migration and mobility (Allison et al. 2012; Stacey et al. 2017; Thorpe et al. 2007; Ushijima and Zayas 1994). For example, many contemporary fishing communities in the Philippines are derived from 'landless and marginal peasants who settled close to the sea and turned to fishing as a main source of livelihood in the twentieth century' (Knudsen 2012: 482; see also Eder 2009; Seki 2000). Second, many forms of coastal tourism tend to have inherent associations with coastal land, such as hotel or resort construction and use of beaches. It is a feature of much coastal tourism that it will interact with coastal residents. As an archipelagic state, in which fishing is a highly significant livelihood activity, the Philippines is an ideal site to study these interactions because large number of people live on the coast and tourism, strongly supported by the government, is rapidly growing (Philippine Statistics Authority 2018). As I argue, the role of land tenure is crucial in these increasingly common fishing-tourism interactions.

\section{Land tenure and coastal rights in the Philippines}

Land reform has a long and contentious history in the Philippines, notably through the Comprehensive Agrarian Reform Program that began in the late 1980s (Borras 2008, 2015). While much land reform is understood to involve transfer of private property rights from large landowners to small landowners and landless farmers (Borras 2006, 2015), in the 
Philippines, many fishers technically live on public land. The Philippine Water Code, introduced in 1976 and based on an 1866 Spanish Law (Valdez 2018), states:

The banks of rivers and streams and the shores of the seas and lakes throughout their entire length and within a zone of three (3) meters in urban areas, twenty (20) meters in agricultural areas and forty (40) meters in forest areas, along their margins are subject to the easement of public use in the interest of recreation, navigation, floatage, fishing and salvage. No person shall be allowed to stay in this zone longer than what is necessary for recreation, navigation, floatage, fishing or salvage or to build structures of any kind (Philippine Water Code: Article 51).

The Fisheries Code of 1998 defines 'foreshore land' as 'a string of land margining a body of water; the part of a seashore between the low water line usually at the seaward margin of a low tide terrace and the upper limit of wave wash at high tide usually marked by a beach scarp or berm' (cited in Batongbakal 2001).

There are numerous other laws relevant to foreshore areas, including the Public Land Act enacted in 1936 and the Civil Code of 1949, as well as diverse legal instruments used to regulate these areas, such as municipal foreshore agreements (e.g. Batongbakal 2001; Knudsen 2012; Valdez 2018). However, the overlapping, unclear and contradictory nature of these laws means that legal interpretation and implementation can be highly variable. As Franco et al. (2015: p. 69) note, 'laws and policies are passed, but they neither self-interpret nor self-implement' (see also Franco 2011). Similarly, with reference to land in Mindanao, Knudsen (2019: p. 8) notes that 'actual land use and local understandings of ownership seldom correlate with legal definitions and classifications'.

Valdez (2018) suggests that different agencies and levels of governments in the Philippines have considerable scope to evict coastal residents in the 'salvage zone'. With reference to a coastal community in Negros Oriental, Knudsen (2012) argues:

There is much scope for interpretation and navigation among those who know how the system works... state institutions have so far first and foremost been keen to develop new instruments to allow outsiders with money to buy, own and lease the coastline and only secondarily concerned with tenure security of low-income coastal dwellers (pp. 485, 497).

This process has been particularly visible in recent years through disaster risk reduction programs and projects (Fitzpatrick and Compton 2014; Morin et al. 2016; Uson 2017; Valdez 2018; Yee 2018). While the Fisheries Code
(RA 8850) advises the Department of Agriculture to relocate fishers near their fishing grounds, implementing rules and regulations are yet to be created and there is a need for better integration of fisherfolk land reform issues with broader land reform processes in the Philippines (Fitzpatrick and Compton 2014). As such, low-income coastal residents in the Philippines tend to hold weak land tenure.

\section{Methods}

This paper draws on long-term ethnographic fieldwork in the community of Esperanza, in the municipality of Coron, Palawan province of the Philippines. I conducted continuous ethnographic research in Esperanza for twelve months in 2006-2007 and returned for short trips in 2009, 2010, 2017 and twice in 2018. I also met with residents of the community in Manila or Puerto Princesa - the provincial capital — each year from 2011 to 2016 and maintained regular, ongoing social contact with some residents through phone, email and social media. The original purpose of the research in 2006-2007 was to investigate the relationship between fishing livelihoods and governance interventions such as marine protected areas (MPAs) (Fabinyi 2012). As tourism became increasingly prevalent in the area, the challenges and opportunities this generated for existing fishing livelihoods subsequently became a key research focus in later visits.

The main method used was participant observation in household and community life, in addition to semistructured and informal interviews that focused on topics of livelihood, fishing, tourism, conservation and marine resources governance (see Bernard 2017; Fabinyi 2012). Interviews were conducted in Filipino, the national lingua franca and spoken by community members. Detailed field notes were taken each day during fieldwork, and these field notes were subsequently qualitatively analysed for key themes that emerged (Bernard 2017). Other data collection tools included a household survey $(n=70)$, accessing government reports and unpublished data, and semi-structured and informal interviews with key stakeholders-tourism operators, government officials and fish traders - in the municipal capital, Coron town.

In 2006, the community had limited engagement with tourism, but by 2017 , tourism was the primary livelihood of most residents. While Esperanza is just one community, this research provides an opportunity to study how tourism has affected individuals, households and the wider community - an opportunity afforded by long-term and return fieldwork engagement with one particular community over long periods of time (e.g. Eder 1999; Knauft 2002; Minnegal and Dwyer 2017). 


\section{Fishing and tourism in Esperanza, Coron}

\section{Coron}

Until the 1990s, the municipality of Coron (see Fig. 1) was largely dependent on fishing as its major economic activity. Located near to some of the most productive fishing grounds in the entire country (Butcher 2004; Spoehr 1980), Coron was an important site for larger vessels based elsewhere in the Philippines that came to fish there and as a desirable 'frontier' settlement for fishing and farming migrants from other islands suffering from poverty and exploitation of natural resources
(Eder 2009; Fabinyi 2014). Important fisheries operating around Coron from the 1960s to 1990s included the anchovy lift net fishery and several small-scale fishing activities, including hook and line, fish traps, net fishing and spearfishing (Fabinyi 2014).

Dive tourism became prominent in Coron from the 1990s, focusing on Japanese World War II shipwrecks. However, tourism expanded rapidly from the late $2000 \mathrm{~s}$ (see Fig. 2) - from well under 10,000 annual arrivals in the 2000 s to nearly 200,000 by 2018 . Such rapid growth has been driven by numerous causes, including promotion of tourism at a national level in the Philippines, promotion

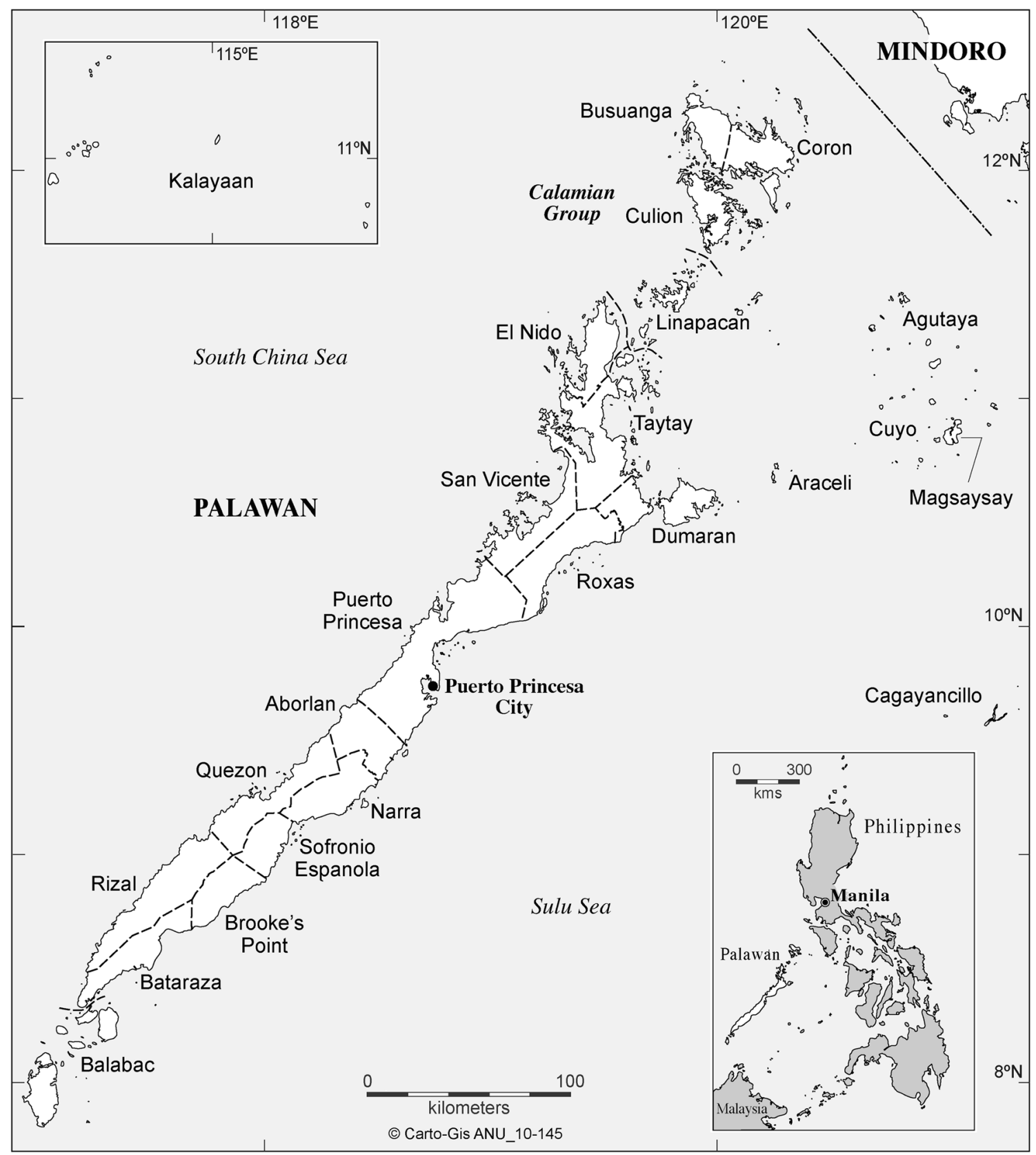

Fig. 1 Map of Palawan province, Philippines 
Fig. 2 Annual arrivals in Coron, 2002-2017
Annual arrivals in Coron, 2002-2017

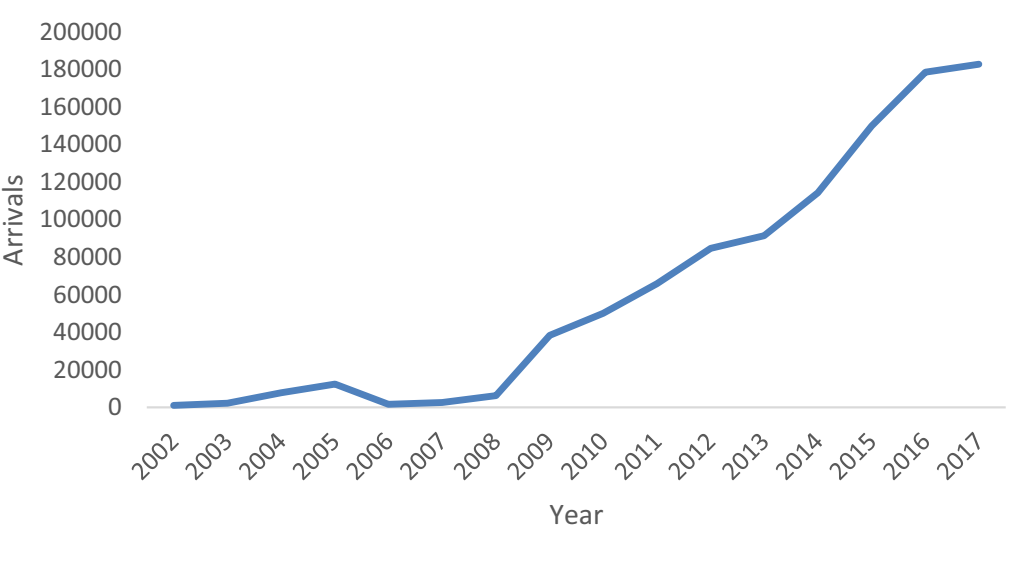

of Palawan as a destination for environmental tourismspurred on by the declaration of the Underground River as one of the New Natural Wonders of the World (see Dressler 2011) - and the specific promotion of Coron as a 'new Boracay' (Fabinyi 2010). Investments from national and international resort chains as well as from government - including a new runway allowing bigger planes to land from 2009-have transformed the visual and financial landscape of the region. Land values have increased and hotels, bars and restaurants are now common throughout the town and its surroundings.

Numerous tourism associations exist and it is difficult to characterise the variety of tourism activities under one type of tourism. In addition to scuba diving, tourism features of Coron include the lakes in Coron Island, as well as beaches, islands and other parts of the region. Tourism ranges from low-end-backpacker dormitories - to highend accommodation options-exclusive resorts upwards of US $\$ 400$ per night. Tourists come from a variety of locations, although the past ten years has seen increasing numbers of Chinese tourists.

The rapid expansion of tourism in Coron has not been uncontested. For example, in 2016-2017, plans were announced for an underwater theme park based on Nickelodeon TV cartoon character, Spongebob's fictional home, Bikini Bottom. A social media campaign was launched 'Coron is not Bikini Bottom' and in late 2017, Viacom, the owner of Nickelodeon, announced that it had abandoned the project. There are also associations dedicated to ensuring the environmental sustainability of tourism in Coron.

\section{Esperanza}

Up until the late 1960s, the coastal area comprising Esperanza was only lightly settled by some indigenous Tagbanua households when several families from the Visayan group of islands in the central Philippines arrived. ${ }^{1}$ Migrants continued to arrive in increasing numbers through the 1970s, 1980s and 1990 s, so that by 2006 , there was a population of 529 . In the mid-2000s, the primary livelihood of almost all residents was fishing. Residents practiced a diversity of gears and techniques that varied throughout the year, depending on season, weather conditions, individual preferences and household economic circumstances. The most common and important type of fisheries included small pump boats with a crew of 2-4 using gillnets to fish for rabbitfish (Siganidae), sold fresh locally or dried in Manila; small pump boats with a crew of 2 4 using hook and line to fish for live grouper (Plectropomus leopardus), exported via Manila to Hong Kong; large vessels with a crew of 10-20 using hook and line to capture fusiliers (Caesio spp.), sold in Manila; and large vessels with a crew of 20-30 using hook and line to capture fresh grouperEpinephelus, sold in Manila, and Plectropomus spp., which were exported.

The rapid growth of tourism has transformed livelihoods in Esperanza. From six fusilier fishing boats that operated out of Esperanza in 2006-2007, only one remains and the others have been sold to tourism operators. Similarly, only one commercial fresh grouper vessel remains, with the other one sold and converted into a tourist boat. Smaller pump boats that used to crew 2-4 people have also been converted into smaller tourist boats that take small groups on daytrips to surrounding beaches. Those with carpentry skills have been busy building new boats. For those who do not own a boat, many have been able to find work as boat hands for other boats, as dive guides, tricycle drivers or in waged labour such as construction. Taking tourists on daytrips is perceived by many former

\footnotetext{
${ }^{1}$ No Tagbanua households now live in Esperanza. For an account of Tagbanua and tourism nearby, see Okazaki (2008), and for a detailed account of the relations between indigenous and migrant groups in the context of economic change elsewhere in Palawan, see Dressler (2009).
} 
fishers as much easier work than the physically and mentally challenging work of fishing, as well as generating more income. Esperanza was positioned to take advantage of the tourist boom as it is less than ten kilometres away from the main town. Being less isolated than many other fishing coastal communities in the Calamianes, Esperanza is also the closest community to an MPA (established in 2005) popular for scuba diving. It also lies near a popular hot spring that attracts many passing tourists.

As opportunities for tourism have increased, fishing opportunities have simultaneously stagnated or declined. Declining fisheries resources have long been noted in the area (e.g. Padilla et al. 2003), as the number of fishers has continuously increased and the technologies used to obtain them have developed. For example, fishers for live groupers must travel to neighbouring municipalities to catch their fish and spend more time at sea than previously (Fabinyi 2010). In recognition of the depleted fisheries resources, stricter governance regimes have been implemented. The Calamianes Islands - the group of four municipalities, of which Coron is part-is now host to more than ten MPAs and new laws were introduced in 2017 to govern the live fish trade, based on closed seasons and size limits. New resorts have employed security guards to informally ban net fishing in reefs near them. While MPAs may serve to increase overall fish stock numbers in surrounding areas over time, they also limit fishing activities in the immediate coastal areas in the short term. Declining fisheries resources and a stricter regulatory environment have provided further incentive to participate in tourism.

The Marquez family provides an illustrative example of how one extended household has diversified and shifted from fishing into tourism. In 2006, household livelihood activities were centred on fishing. The family owned two commercial fishing vessels. ${ }^{2}$ One vessel was captained by the father of the household and he went fishing in the South China Sea and Mindanao for grouper, which was subsequently exported to Taiwan via Manila. The second boat was captained by the mother's brother and went fishing for fusiliers around Palawan, which were subsequently sold in Manila. Their son-in-law also operated a fish cage that grew out live grouper, sold to local traders and bound them for export to Hong Kong. Two sons based in Manila assisted with the logistics of the fish sales in Manila.

By 2017, the father's vessel was the family's only fishing operation. This vessel regularly fished in the South China Sea and Mindanao, although by 2017 they were barely earning enough to cover their costs, so the vessel was sold in 2018 . The elder son, who had previously been based in Manila helping with fish sales logistics, was based in Esperanza by 2017, working as a local tour guide and taking tourists snorkelling in

\footnotetext{
${ }^{2}$ In the Philippines, commercial fishing vessels are defined as those of three gross tons or more.
}

the local marine park or to the nearby hot springs. He and his wife converted one building into a homestay for visiting backpackers and set up a restaurant. The son-in-law who had previously operated the fish cage now operated a glass-bottom boat that took tourists, such as the elderly and those with less swimming ability, out to the marine park. The other son, who had previously been based in Manila assisting with fish sales logistics, now operated a grocery store in town, close to several hotels. Most business comes from tourists and, with the profits from this store, he has invested in two small boats that are operated by friends in Esperanza, which take tourists on daytrips. The daughter married someone from a larger city, obtaining loans from friends and acquaintances to rent a small space in town to set up a bar catering to backpackers.

However, the transition from fishing to tourism has neither been straightforward nor entirely positive. Neighbouring communities less well positioned than Esperanza, such as those in more remote islands, have had fewer tourists visiting. Some residents are shy to use English or to engage with foreigners. The boom in tourism and the fewer numbers of fishers in the area has meant that the price of fish and other household goods has increased, raising the cost of living. For example, 'secondclass' rabbitfish (Siganidae) that were sold at PHP40 per kilogramme are now double the price. There are also tensions regarding the development of an eco-tourism association in the community that aims to manage all tourism for the nearby MPA and strains within extended families between those who feel excluded from the benefits - an example of what Hall et al. (2011) term 'intimate exclusions'.

Underlying these developments are land rights tensions. While there have been several attempts by local political families based in town to claim the land of Esperanza, one case has been particularly high profile. A wealthy family based in town claimed to own the coastal land, with a title dating from the early twentieth century. While this family was nonresident for many years, since at least the early 2000s, the family has been campaigning through legal challenges to evict the residents from Esperanza. Their apparent aim has been to replace them with new tourism developments. While the legal challenges have stagnated and progressed very slowly through the legal system, residents of Esperanza allege that the family has been able to influence local politicians, to support them and prevent local residents from effectively using the land. First, residents have been unable to take advantage of the soaring prices of land sales. There is a ban on developing new cement structures on coastal land due to legal proceedings, meaning that residents cannot develop resorts or tourism accommodation, or even develop their own housing. After Typhoon Haiyan devastated many homes in 2013, residents claimed that they were prevented from accessing new housing materials provided by relief organisations. Other ways in which the family is alleged to have prevented infrastructure development include preventing the planned cementing of the 
road into the community and stopping regular electricity supply to the community.

Most significant is the threat of relocation, which would mean a significant upheaval to the lives and livelihoods of residents in Esperanza. For example, one proposed relocation site was many kilometres inland. Residents have continued to resist this prospect by speaking up in public hearings - the main formal avenue for registering their concerns. They have also voted for local politicians who support them in the dispute (e.g. providing funds for a lawyer), which has meant that instead of clear-cut coastal grabbing proceeding in practice, the outcome to date has been a murky stalemate. Residents continue to live in their homes and practise their livelihood activities. However, the threat of relocation means that their livelihoods are insecure. Many residents are angry about the legal dispute. One elderly woman bitterly exclaimed, 'I have lived here for more than fifty years! My children were all born here, this is our home!' Others are anxious, as one man explained, 'We have done our best here, but if we are moved I don't know what will happen. Sometimes I lie in bed thinking about all the bad things that could happen. So we just pray to God'. Residents believe that the length of time many have lived there confers them legitimacy and that moves to evict them would generate large negative social effects.

A further set of tensions over coastal land in Esperanza emerged in 2018, deriving directly from the government. Earlier in the year, President Duterte declared that the wellknown tourist hub, Boracay, was a 'cesspool' and closed it for six months. Other coastal tourist hubs in the country, including Puerto Galera in Mindoro Oriental, El Nido-further south in Palawan province - and Coron, have also been cited in national media as also being of concern (Rey 2018). In May 2018, 75 businesses and households in Coron received a 'notice to vacate' from the Department of Environment and Natural Resources (DENR) (Fabro 2018). These notices cited Presidential Decree 705, the Revised Forestry Code of the Philippines (1975), and declared that recipients' structures were located in a 'timberland' area. As such, they were in violation of the Forestry Code of the Philippines and were required to vacate within thirty days. If they were not to comply, the notice advised that it would refer the matter to the local government to "conduct demolition of illegal structures; or we will file appropriate case/s against you before the proper court...We are hoping you will give this matter your preferential and utmost attention in order to avoid a costly litigation'.

The declaration of being located in 'timberlands' was unusual as the maps these classifications were based on were from 1914 during the period of American colonialism. They had been superseded by many other zoning maps, including those of the local government and by the provincial government's 'environmentally critical area network' zones. It was also strange, given that in many cases, the DENR had itself approved the Environmental Compliance Certificates several years earlier. Moreover, the local government had been collecting land taxes on many of these structures, which meant that they were legitimate in the eyes of the local government. The notices to vacate were also undermined by the fact that the municipal government had itself embarked on an extensive project of land reclamation over the past decade in the town area.

The eviction notices were received with surprise, confusion, anxiety and anger by local residents. For example, one resident noted, 'We have lived here for a long time, and now somebody rich will show up and force us to leave. We cannot fight because they have a higher profile, we are just ordinary people' (Popplewell 2019). Another argued that his investments in building tourism accommodations over the past year may be wasted if they were to be evicted. As one fisher explained, 'Most of us here are fishermen; if they move us to the mountains, then we cannot live there. It's like a fish being brought up to land' (Popplewell 2019).

In interviews with key municipal officials, it became apparent that despite many reasons for the legal notices to vacate being absurd, this was a means by which the DENR could implement the wishes of President Duterte to 'clean up' Coron (Rey 2018). The acting DENR chief officer in Coron was explicit about the need for cleaning up the environment, arguing 'If the environment is not good, then no tourists will come...If I were the mayor, I would put up establishments there [in coastal villages]. Commercial, not residential, because residents are a big contributor to the pollution' (Popplewell 2019). Officials spoke of the need to reduce pollution in Coron Bay, while others argued for the need to better prepare for future disasters such as typhoons. During further negotiations, the local mayor has proposed the construction of communal septic tanks along the coastline as a solution for the problem of faecal coliform pollution.

It seems that, for the time being, residents of Esperanza and other coastal areas of Coron will not be evicted. However, what both land disputes highlight is the weak nature of coastal land tenure and how conflicting laws and policies can be abused by those with power (Franco et al. 2015; Knudsen 2012). National laws, such as those cited by the DENR, conflict with those of the provincial government and with the rights of the local governments under the Local Government Unit Code of 1991. In the context of pressure coming directly from President Duterte, the DENR interpretation gained increased legitimacy.

\section{Discussion and conclusion}

In the space of ten years, Esperanza has changed from a community dominated by fishing to one dominated by tourism. The growth of tourism in and around the fishing community of Esperanza has provided fishers with expanded 
opportunities to earn income, from boat building to working as tourism guides. While most residents would agree with the proposition that tourism has provided a lucrative alternative livelihood to fishing, this is not the only concern of fishers. In conjunction with the growth of tourism, pressure on coastal land has escalated on multiple fronts. Ongoing land disputes have meant that residents have been unable to fully capitalise on the tourism boom while the threat of eviction poses an immediate threat to livelihood security. While there has been no clear case of land or coastal grabbing, or accumulation by dispossession - as residents continue to live there despite multiple pressures (cf Knudsen 2012; Menon et al. 2018)-fishers hold limited rights to negotiate the tourism boom and obtain its full benefits. For example, by not maintaining clear ownership rights, residents are unable to sell their land and have been constrained in the ability to build new structures. In this sense, fishers have seen a rise in income, yet limited increases in wealth. Further, the lack of secure tenure generates considerable anxieties and uncertainties about future household livelihood strategies.

This case study has therefore highlighted a range of processes by which land tenure is central to how those involved in fishing livelihoods negotiate the tourism boom, many of which may be relevant for other locations: ${ }^{3}$

- Potential displacement through pressure from tourism developers

- Potential displacement through 'disaster capitalism' (Klein 2007), i.e. how increasing awareness and implementation of disaster risk reduction measures may be linked to plans for tourism developments

- The crucial role of the state: both through enacting relevant legislation and through the ways such legislation is implemented and interpreted by local politicians (Franco et al. 2015)

- How claims of 'belonging' and identity as a fisher can be used to resist displacement

- How weak land tenure shapes the livelihood decisions of coastal residents (e.g. how it limits farming options, and influences the ways in which residents are able to participate in tourism activities that use land)

- How weak land tenure limits the ability of residents to sell land for high prices

In the context of small-scale fisheries research, weak coastal land tenure is a problem not isolated to the Philippines (Allison et al. 2012; Bavinck et al. 2017; McDonnell 2018; Stacey et al. 2017). For small-scale fishers, the problem of weak coastal land tenure is highlighted by the growth of coastal tourism. Interlinked with wider processes of economic and social transformation along the coasts (e.g. expansion of

\footnotetext{
${ }^{3}$ I am grateful to an anonymous reviewer for suggesting this point.
}

marine protected areas, increasing aquaculture), the growth of coastal tourism and its interactions with forms of land tenure reflects processes of contested frontier-making that are likely to intensify the 'spatial squeeze' facing many smallscale fishers globally (Bavinck et al. 2017; Bavinck et al. 2018; Cohen et al. 2019; Fabinyi et al. 2019; Said et al. 2017).

While improved land rights has long been on the agenda in terrestrial areas, and in related studies of agrarian change (Peluso and Lund 2011; Hall et al. 2011), discussions of land rights among coastal residents has so far mostly been linked to discussions of disaster risk reduction programs that involve relocations (e.g. Fitzpatrick and Compton 2014). The FAO (2015) small-scale fisheries guidelines provide aspirational voluntary guidelines that governments can aspire to, and they include references to land, for example in Section 5.3:

States, in accordance with their legislation, should ensure that small-scale fishers, fish workers and their communities have secure, equitable, and socially and culturally appropriate tenure rights to fishery resources (marine and inland) and small-scale fishing areas and adjacent land, (see also Section 5.4).

To date, however, few studies on and actions taken in implementation of these guidelines have focused explicitly on coastal land tenure (Jentoft et al. 2017). In the Philippines, as elsewhere, there is a clear role for the state to provide better instruments that can clarify the situation in favour of fishers (Borras 2001). Although there are laws that support the rights of small-scale fisherfolk - such as those in the Fisheries Code of 1998 - the ways in which governments at multiple levels in the Philippines have interpreted these laws in practice has not generally been in favour of small-scale fishers (Knudsen 2012; Valdez 2018). Given that the Philippines now operates under what has been termed a 'fascist leader' (Bello 2017), initiatives for substantive land reforms deriving from the state may be limited. There is therefore a need for further work by concerned scholars, land reform groups and small-scale fisherfolk organisations to lobby for the improvement of land tenure conditions for coastal residents.

Funding Information Australian Research Council (DP180100965).

\section{Compliance with ethical standards}

Conflict of interest The author declares that there is no conflict of interest.

Open Access This article is distributed under the terms of the Creative Commons Attribution 4.0 International License (http:// creativecommons.org/licenses/by/4.0/), which permits unrestricted use, distribution, and reproduction in any medium, provided you give appropriate credit to the original author(s) and the source, provide a link to the Creative Commons license, and indicate if changes were made. 


\section{References}

Akram-Lodhi, A.H., and C. Kay. 2010. Surveying the agrarian question (Part 1): Unearthing foundations, exploring diversity. The Journal of Peasant Studies 37 (1): 177-202. https://doi.org/10.1080/ 03066150903498838.

Allison, E.H., B.D. Ratner, B. Åsgård, R. Willmann, R. Pomeroy, and J. Kurien. 2012. Rights-based fisheries governance: From fishing rights to human rights. Fish and Fisheries 13 (1): 14-29.

Batongbakal, J 2001. A crowded shoreline: Review of the Philippines' foreshore and shore land management policies. The Coastal Resource Management Project of the Department of Environment and Natural Resources.

Bavinck, M., F. Berkes, A. Charles, A.C.E. Dias, N. Doubleday, P. Nayak, and M. Sowman. 2017. The impact of coastal grabbing on community conservation: A global reconnaissance. Maritime Studies 16 (1): 8. https://doi.org/10.1186/s40152-017-0062-8.

Bavinck, M., S. Jentoft, and J. Scholtens. 2018. Fisheries as social struggle: A reinvigorated social science research agenda. Marine Policy 94: 46-52.

Bello, W. 2017. Rodrigo Duterte: A fascist original. In A Duterte reader: Critical essays on Rodrigo Duterte's early presidency, ed. N. Curato, 77-91. Quezon City: Ateneo de Manila University Press.

Belton, B., and S.H. Thilsted. 2014. Fisheries in transition: Food and nutrition security implications for the global South. Global Food Security 3 (1): 59-66.

Benjaminsen, T.A., and I. Bryceson. 2012. Conservation, green/blue grabbing and accumulation by dispossession in Tanzania. Journal of Peasant Studies 39 (2): 335-355.

Bennett, N.J. 2018a. Navigating a just and inclusive path towards sustainable oceans. Marine Policy 97: 139-146.

Bennett, N.J. 2018b. In political seas: Engaging with political ecology in the ocean and coastal environment. Coastal Management. 47: 6787. https://doi.org/10.1080/08920753.2019.1540905.

Bennett, N.J., H. Govan, and T. Satterfield. 2015. Ocean grabbing. Marine Policy 57: 61-68.

Bernard, H.R. 2017. Research methods in anthropology: Qualitative and quantitative approaches. Lanham, MD: Rowman \& Littlefield.

Bernstein, H. 2006. Is there an agrarian question in the 21st century? Canadian Journal of Development Studies/Revue canadienne d'études du développement 27 (4): 449-460.

Betcherman, G., and M. Marschke. 2016. Coastal livelihoods in transition: How are Vietnamese households responding to changes in the fisheries and in the economy? Journal of Rural Studies 45: 24-33.

Borras, S.M. 2001. State-society relations in land reform implementation in the Philippines. Development and change 32 (3): 545-575.

Borras, S.M. 2006. Redistributive land reform in 'public' (forest) lands? Lessons from the Philippines and their implications for land reform theory and practice. Progress in Development Studies 6 (2): 123145.

Borras, S.M. 2008. Competing views and strategies on agrarian reform. Quezon City: Ateneo de Manila University Press.

Borras, S.M. 2015. Pro-poor land reform: A critique. Ottowa: Les Presses de l'Université d'Ottawa.

Borras, S.M., R. Hall, I. Scoones, B. White, and W. Wolford. 2011. Towards a better understanding of global land grabbing: An editorial introduction. The Journal of Peasant Studies 38 (2): 209-216.

Butcher, J. 2004. The closing of the frontier. Singapore: Institute of Southeast Asian Studies.

Cheong, S.M. 2005. Korean fishing communities in transition: Limitations of community-based resource management. Environment and Planning A 37 (7): 1277-1290.

Cohen, P., E.H. Allison, N.L. Andrew, J.E. Cinner, L.S. Evans, M. Fabinyi, L.R. Garces, S.J. Hall, C.C. Hicks, T.P. Hughes, and S.
Jentoft. 2019. Securing a just space for small-scale fisheries in the blue economy. Frontiers in Marine Science 6: 171.

DA-BFAR. 2004. In turbulent seas: The status of Philippine marine fisheries. Cebu City: Department of Agriculture and Bureau of Fisheries and Aquatic Resources (DA-BFAR).

Davis, A., and K. Ruddle. 2012. Massaging the misery: Recent approaches to fisheries governance and the betrayal of small-scale fisheries. Hum Organ 71 (3): 244-254.

Depondt, F., and E. Green. 2006. Diving user fees and the financial sustainability of marine protected areas: Opportunities and impediments. Ocean Coastal Manage 49: 188-202.

Dodds, R. 2007. Malta's tourism policy: Standing still or advancing towards sustainability? Island Studies Journal 2 (1): 47-66.

Dressler, W. (2009). Old thoughts in new ideas. State conservation measures, development and livelihood on Palawan Island. Quezon City: Ateneo de Manila University Press.

Dressler, W.H. 2011. First to third nature: The rise of capitalist conservation on Palawan Island, the Philippines. Journal of Peasant Studies 38 (3): 533-557.

Dwyer, L. 2018. Tourism development in the blue economy. The Blue Economy Handbook of the Indian Ocean Region 299.

Eder, J.F. 1999. A generation later: Household strategies and economic change in the rural Philippines. Honolulu: University of Hawaii Press.

Eder, J.F. 2009. Migrants to the coasts: Livelihood, resource management, and global change in the Philippines. Wadsworth, CT: Cengage Learning.

European Commission. 2014. Coastal and maritime tourism. https://ec. europa.eu/maritimeaffairs/policy/coastal_tourism_en. Accessed 9 March 2019.

Fabinyi, M. 2010. The intensification of fishing and the rise of tourism: Competing coastal livelihoods in the Calamianes Islands, Philippines. Human Ecology 38 (3): 415-427.

Fabinyi, M. 2012. Fishing for fairness: Poverty, morality and marine resource regulation in the Philippines. Canberra: ANU Press.

Fabinyi, M. 2014. Fishing and socio-economic change in the Calamianes Islands. In Palawan and its global connections, 140-160. Manila: Ateneo de Manila University Press.

Fabinyi, M., W. Dressler, and M. Pido. 2019. Access to fisheries in the maritime frontier of Palawan Province, Philippines. Singapore Journal of Tropical Geography 40 (1): 92-110.

Fabro, Keith. 2018. DENR gives 75 business owners in Coron a month to remove illegal structures. Rappler. https://www.rappler.com/ business/200627-deadline-coron-palawan-business-owners-illegalstructures. Accessed 9 March 2019.

Fairhead, J., M. Leach, and I. Scoones. 2012. Green grabbing: A new appropriation of nature? Journal of Peasant Studies 39 (2): 237 261.

FAO. 2015. Voluntary Guidelines for Securing Sustainable Small-Scale Fisheries in the Context of Food Security and Poverty Eradication. Food and Agriculture Organization of the United Nations. http:// www.fao.org/3/i4356en/I4356EN.pdf. Accessed 9 March 2019.

Fitzpatrick, D. and C. Compton. 2014. Beyond safe land: Why security of land tenure is crucial for the Philippines' post-Haiyan recovery. Oxfam Briefing Paper. https://policy-practice.oxfam.org.uk/ publications/beyond-safe-land-why-security-of-land-tenure-iscrucial-for-the-philippines-pos-324557. Accessed 9 March 2019.

Foale, S., P. Cohen, S. Januchowski-Hartley, A. Wenger, and M. Macintyre. 2011. Tenure and taboos: Origins and implications for fisheries in the Pacific. Fish and Fisheries 12 (4): 357-369.

Franco, J.C. 2011. Bound by law: Filipino rural poor and the search for justice in a plural-legal landscape. Quezon City: Ateneo de Manila University Press.

Franco, J.C., S. Monsalve, and S.M. Borras. 2015. Democratic land control and human rights. Current Opinion in Environmental Sustainability 15: 66-71. 
Gibson, K., A. Cahill, and D. McKay. 2010. Rethinking the dynamics of rural transformation: Performing different development pathways in a Philippine municipality. Transactions of the Institute of British Geographers 35 (2): 237-255.

Gössling, S., ed. 2003. Tourism and development in tropical islands: Political ecology perspectives. Cheltenham: Edward Elgar.

Grydehøj, A., and P. Hayward. 2014. Social and economic effects of spatial distribution in island communities: Comparing the Isles of Scilly and Isle of Wight, UK. Journal of Marine and Island Cultures 3 (1): 9-19.

Hall, D. 2013. Primitive accumulation, accumulation by dispossession and the global land grab. Third World Quarterly 34 (9): 1582-1604.

Hall, D., P. Hirsch, and T.M. Li. 2011. Powers of exclusion: Land dilemmas in Southeast Asia. Honolulu: University of Hawai'i Press.

Hill, A. 2017. Blue grabbing: Reviewing marine conservation in Redang Island Marine Park, Malaysia. Geoforum 79: 97-100.

Hoefle, S.W. 2014. Fishing livelihoods, seashore tourism, and industrial development in coastal Rio de Janeiro: Conflict, multi-functionality, and juxtaposition. Geographical Research 52 (2): 198-211.

Jentoft, S., R. Chuenpagdee, M.J. Barragán-Paladines, and N. Franz, eds. 2017. The small-scale fisheries guidelines: Global implementation. Cham: Springer.

Kerkvliet, B.J. 2002. The Huk rebellion: A study of peasant revolt in the Philippines. Lanham, MD: Rowman \& Littlefield Publishers.

Klein, N. 2007. The shock doctrine: The rise of disaster capitalism. London: Macmillan.

Knauft, B.M. 2002. Exchanging the past: A rainforest world of before and after. Chicago, IL: University of Chicago Press.

Knudsen, M. 2012. Fishing families and cosmopolitans in conflict over land on a Philippine island. Journal of Southeast Asian Studies 43 (3): 478-499.

Knudsen, M. 2016. Poverty and beyond: Small-scale fishing in overexploited marine environments. Human Ecology 44 (3): 341352

Knudsen, M. 2019. Agrarian transition in the southern Philippines: More than poverty, dispossession, and violence. Critical Asian Studies. https://doi.org/10.1080/14672715.2019.1571427.

Majanen, T. 2007. Resource use conflicts in Mabini and Tingloy, the Philippines. Marine Policy 31 (4): 480-487.

McDonnell, S. 2018. Selling 'sites of desire': Paradise in reality television, tourism, and real estate promotion in Vanuatu. The Contemporary Pacific 30 (2): 413-435.

Menon, A., M. Sowman, and M. Bavinck. 2018. Rethinking capitalist transformation of fisheries in South Africa and India. Ecology and Society 23 (4): 27.

Miller, K. 2018. Promise or peril: The role of tourism in transforming small-scale fisheries. Paper presented at the 3rd World Small-Scale Fisheries Congress, October 22-26, Chiang Mai.

Minnegal, M., and P.D. Dwyer. 2017. Navigating the future: An ethnography of change in Papua New Guinea. Canberra: ANU Press.

Morin, V.M., M.M. Ahmad, and P. Warnitchai. 2016. Vulnerability to typhoon hazards in the coastal informal settlements of metro Manila, the Philippines. Disasters 40 (4): 693-719.

Ojeda, D. 2012. Green pretexts: Ecotourism, neoliberal conservation and land grabbing in Tayrona National Natural Park, Colombia. Journal of Peasant Studies 39 (2): 357-375.

Okazaki, E. 2008. A community-based tourism model: Its conception and use. Journal of sustainable tourism 16 (5): 511-529.

Oracion, E.G., M.L. Miller, and P. Christie. 2005. Marine protected areas for whom? Fisheries, tourism, and solidarity in a Philippine community. Ocean Coastal Management 48: 393-410.

Padilla, J.E., S. Mamauag, G. Braganza, N. Brucal, D. Yu, and A. Morales. 2003. Sustainability assessment of the live reef-fish for food industry in Palawan Philippines. Quezon City: WWFPhilippines.
Papageorgiou, M. 2016. Coastal and marine tourism: A challenging factor in marine spatial planning. Ocean \& Coastal Management 129: $44-48$.

Pauly, D., and D. Zeller. 2016. Catch reconstructions reveal that global marine fisheries catches are higher than reported and declining. Nature Communications 7: 10244.

Peluso, N.L., and C. Lund. 2011. New frontiers of land control: Introduction. Journal of Peasant Studies 38 (4): 667-681.

Philippine Statistics Authority. 2018. Contribution of tourism to the economy is 12.2 percent in 2017. Https://psa.gov.ph/tourism-satelliteaccounts-press-releases. Accessed 9 March 2019.

Philippine Water Code 1976. Presidential Decree no. 1067 December 31, 1976: A decree instituting a water code, thereby revising and consolidating the laws governing the ownership, appropriation, utilization, exploitation, development, conservation and protection of water resources. https://lawphil.net/statutes/presdecs/pd1976/pd 1067 1976.html.

Popplewell, Elyse. 2019. Eviction notice sparks confusion in Coron. The Manila Times. https://www.manilatimes.net/eviction-notice-sparksconfusion-in-coron/498031/.

Porter, B.A., M.B. Orams, and M. Lück. 2015. Surf-riding tourism in coastal fishing communities: A comparative case study of two projects from the Philippines. Ocean and Coastal Management 116: $169-176$.

Rey, Aika. 2018. Which tourist spots will be rehabilitated after Boracay? Rappler. https://www.rappler.com/nation/205048-list-touristdestinations-for-rehabilitation-after-boracay. Accessed 9 March 2019

Ribot, J.C., and N.L. Peluso. 2003. A theory of access. Rural Sociology 68 (2): $153-181$

Ruddle, K., and A. Satria, eds. 2010. Managing coastal and inland waters: Pre-existing aquatic management systems in Southeast Asia. Dordrecht: Springer.

Said, A., D. MacMillan, M. Schembri, and J. Tzanopoulos. 2017. Fishing in a congested sea: What do marine protected areas imply for the future of the Maltese artisanal fleet? Applied Geography 87: 245255.

Seki, K. 2000. Wherever the waves carry us: Historical development of a Visayan fisherfolk's livelihood strategies. Philippine Quarterly of Culture and Society 28 (2): 133-157.

Sikor, T., and C. Lund. 2009. Access and property: A question of power and authority. Development and Change 40 (1): 1-22.

Silver, J.J., N.J. Gray, L.M. Campbell, L.W. Fairbanks, and R.L. Gruby. 2015. Blue economy and competing discourses in international oceans governance. The Journal of Environment and Development 24 (2): $135-160$.

Spoehr, A. 1980. Protein from the sea: Technological change in Philippine capture fisheries. Pittsburgh, PA: University of Pittsburgh.

Stacey, N., G. Acciaioli, J. Clifton, and D.J. Steenbergen. 2017. Impacts of marine protected areas on livelihoods and food security of the Bajau as an indigenous migratory people in maritime Southeast Asia. In Marine protected areas: Interactions with fishery livelihoods and food security, ed. L. Westlund, A. Charles, S.M. Garcia, and J. Sanders, 113-126. Rome: Food and Agriculture Organisation of the United Nations.

Su, M.M., G. Wall, and M. Jin. 2016. Island livelihoods: Tourism and fishing at Long Islands, Shandong Province, China. Ocean \& Coastal Management 122: 20-29.

Su, M.M., G. Wall, and S. Wang. 2017. Yujiale fishing tourism and island development in Changshan Archipelago, Changdao, China. Island Studies Journal 12 (2): 127-142.

Terk, E., and N. Knowlton. 2010. The role of SCUBA diver user fees as a source of sustainable funding for coral reef marine protected areas. Biodiversity 11 (1-2): 78-84. 
Thorpe, A., N.L. Andrew, and E.H. Allison. 2007. Fisheries and poverty reduction. CAB Review in Agriculture, Veterinary Science, Nutrition and Natural Resources 2 (85).

Tsartas, P. 2003. Tourism development in Greek insular and coastal areas: Sociocultural changes and crucial policy issues. Journal of Sustainable Tourism 11 (2-3): 116-132.

UNWTO. 2019. International tourist arrivals reach 1.4 billion two years ahead of forecasts. United Nations World Tourism Organization. http://www2.unwto.org/press-release/2019-01-21/internationaltourist-arrivals-reach-14-billion-two-years-ahead-forecasts. Accessed 9 March 2019.

Ushijima, I. and C.N. Zayas. eds. 1994. Fishers of the Visayas. CCSP Publications, College of Social Sciences and Philosophy, University of the Philippines.

Uson, M.A.M. 2017. Natural disasters and land grabs: The politics of their intersection in the Philippines following super typhoon Haiyan. Canadian Journal of Development Studies/Revue canadienne d'études du développement 38 (3): 414-430.

Valdez, A.I.A. 2018. The paradox of the salvage zone: Examining the Philippine coastal adaptation framework in the light of tropical cyclones and threats of sea level rise. Centre for Resources, Energy and
Environmental Law, University of Melbourne. https://law.unimelb. edu.au/centres/creel/research/publications/thesis-and-workingpapers.

Voyer, M., G. Quirk, A. Mcllgorm, and K. Azmi. 2018. Shades of blue: What do competing interpretations of the Blue Economy mean for oceans governance? Journal of Environmental Policy and Planning 20 (5): 595-616.

White, A.T., and R. Rosales. 2003. Community-oriented marine tourism in the Philippines: Role in economic development and conservation. In Tourism and development in tropical islands: Political ecology perspectives, ed. S. Gössling, 237-262. Cheltenham: Edward Elgar Publishing Ltd.

Wolf, E.R. 1999. Peasant wars of the twentieth century. Norman, OK: University of Oklahoma Press.

Yee, D.K.P. 2018. Constructing reconstruction, territorializing risk: Imposing 'no-build zones' in post-disaster reconstruction in Tacloban City, Philippines. Critical Asian Studies 50 (1): 103-121.

Publisher's note Springer Nature remains neutral with regard to jurisdictional claims in published maps and institutional affiliations. 